\section{Loyalitas Kreativitas \\ Aldi Masyarakat Kreatif}

P-ISSN 2722-2101, E-ISSN 2722-4201

Program Studi Ekonomi Manajemen Universitas Pamulang

Jurnal LOKABMAS Kreatif Vol. 01, No. 01, Hal. 56- 62

Email:jurnalkreatif.manajemen@gmail.com

\title{
PENTINGNYA PENDIDIKAN LITERASI KEUANGAN DI LINGKUNGAN KELUARGA (DI MAJELIS TA'LIM AL HIDAYAH BENDA BARU PAMULANG TANGERANG SELATAN)
}

\author{
Gunartin $^{1}$, Rusmaini $^{2}$, Pantja $^{3}$, Surasni $^{4}$, Metha $^{5}$ \\ Dosen Pendidikan Ekonomi FKIP Universitas Pamulang \\ Email : dosen01339@unpam.ac.id,dosen02066@unpam.ac.id, dosen01827@unpam.ac.id, \\ dosen01520@unpam.ac.id
}

\begin{abstract}
ABSTRAK
Pengabdian dengan judul Pentingnya Pendidikan Literasi Keuangan Di Lingkungan Keluarga (Di Majelis Ta'lim Al Hidayah Benda Baru Pamulang Tangerang Selatan) ini merupakan implementasi dari pengabdian kepada masyarakat dengan tujuan membantu memberikan pemahaman pentingnya pendidikan literasi keuangan di lingkungan keluarga sehingga setiap angota keluarga dapat menghargai keamanan secara finansial. Memberikan pemahaman bagaimana pengelolaan keuangan yang efektif dan efisien sehingga kesejahteraan ekonomi keluarga dapat diwujudkan dengan keamanan finansial.Metode pelaksanaan dalam kegiatan program pengabdian kepada masyarakat ini diawali surve dan pendekatan kepada ketua Majelis Ta' lim Al Hidayah dengan menyampaikan maksud serta tujuan dilakukan kegiatan ini. Pada surve awal juga disampaikan rencana pelaksanaan dan sharing tema pengabdian agar kegiatan pengabdian ini tepat sasaran serta berjalan lancar. Pelaksanaan pengabdian kepada masyarakat dilakukan oleh tim dosen Program Studi Pendidikan Ekonomi FKIP Universitas Pamulang dengan 7 anggota, 5 dosen dan 2 mahasiswa. Materi dari tema pengabdian dilakukan oleh tim dosen sendiri sebagai narasumber. Hasil dari kegiatan pengabdian ini dapat ditarik kesimpulan bahwa masih banyak keluarga yang pengelolaan keuangan masih konvensional belum sampai ke ranah investasi untuk passive incame. Untuk jangka panjang investasi menjadi sangat penting ditinjau dari keamanan finansial pada saat usia sudah tidak lagi produktif. Adapun harapan diselenggarakan kegiatan pengabdia kepada masyarakat dengan judul Pentingnya Pendidikan Literasi Keuangan Di Lingkungan Keluarga (Di Majelis Ta'lim Al Hidayah Benda Baru Pamulang Tangerang Selatan) ini, masyarakat khususnya jama'an Majelis Ta'lim Al HIdayah dapat meningkatkan kemampuannya dalam memgelola keuangan (literasi keuangan) secara efektif dan efisien.
\end{abstract}

\section{Kata Kunci: Pendidikan, Literasi Keuangan, Keluarga}

\begin{abstract}
ABSTRAC
Dedication with the title The Importance of Financial Literacy Education in the Family Environment In the Al Hidayah Benda Body of the New Object Pamulang South Tangerang is an implementation of community service with the aim of helping to provide an understanding of the importance of financial literacy education in the family environment so that each family member can appreciate financial security . Provide an understanding of how effective and efficient financial management so that family economic prosperity can be realized with financial security. The method of implementation in the community service program activities was initiated by the survey and approach to the chairman of the Al Hidayah Ta'lim Assembly by conveying the intent and purpose of this activity. In the initial survey, it was also conveyed the implementation plan and sharing of community service themes so that the service activities were on target and run smoothly. The community service was carried out by the lecturer team of the Faculty of Economic Education Study Program Pamulang University with 7 members, 5 lecturers and 2 students. Material from the theme of devotion was carried out by the lecturer team itself as the resource person. The results of the community service activities can be concluded that there are still many families
\end{abstract}




\section{Loyalitas Kreativitas \\ Aldi Masyarakat Kreatif}

P-ISSN 2722-2101, E-ISSN 2722-4201

Program Studi Ekonomi Manajemen Universitas Pamulang

Jurnal LOKABMAS Kreatif Vol. 01, No. 01, Hal. 56- 62

Email:jurnalkreatif.manajemen@gmail.com

whose financial management is still conventional and have not yet reached the realm of investment for passive incame. In the long run, investment becomes very important in terms of financial security at the age when it is no longer productive. The hope is that community service activities will be held under the title Importance of Financial Literacy Education in the Family Environment in the Al Hidayah Ta'lim Assembly of New Objects of Pamulang, South Tangerang, the community, especially the Jama'ah of the Ta'lim Al HIdayah, can improve their ability to manage finances (financial literacy ) effectively and efficiently.

Keywords: Education, Financial Literacy, Family

\section{PENDAHULUAN}

Pendidikan merupakan proses upaya secara sadar untuk menumbuhkembangkan potensi sumber daya manusia.Memiliki pengetahuan dan keterampilan, kesehatan jasmani dan rohani, kepribadian baik dan mandiri serta tanggung jawab merupakan karakter dari pendidikan.

Pendidikandiawali dari lingkungan keluarga dimana individu tersebut dilahirkan.Pendidikan mempunyai kontribusi yang cukup besar dalam membentuk literasi keuanganbaik pendidikan formal maupun pendidikan informal di lingkungan keluarga.Literasi keuangandi tingkat pendidikan informal dibentuk oleh peran orang tua yang telah memberikan pendidikan bagaimana mengelola keuangan yang baik dengan cara memperkenalkan nilai-nilai sederhana dan sikap hidup yang menghargai jerih payah orang tua agar dapat memenuhi kebutuhan, memiliki cadangan dalam bentuk tabungan dan juga mampu berinvestasi, sekaligus menjadi suri teladan bagi anakanaknya. Segala sesuatu yang dilakukan secara berulang dan rutin dalam waktu lama akan menjadi kebiasaan. Pendidikan literasi keuangan yang sudah ditanamkan sejak dini tentuakan berdampak pada pola literasi keuangan pada anggota keluarga, karena proses pembelajaran di tingkat pendidikan juga menentukan proses pembentukan literasi keuangan pada anak diusia dewasa nanti.

Tingkat kemampuan ekonomi orang tua juga turut berperan dalam menentukan kemampuan anak mengelola keuangannya.Hal ini didukung oleh Gutter, 2018 (dalam Wijayati) bahwa pengetahuan tentang keuangan berbanding lurus dengan pengetahuan, sikap, ekonomi orang tua dan perilaku terhadap keuangan. Meskipun sudah dibekali dengan pengetahuan tentang bagaimana mengelola keuangan secara cerdas dengan porsi yang samaoutput dari hasil capaian pembelajaran tidak bisa disamakan untuk masing-masing anak, sehingga pada prinsipnya materi teoritis hanya menjadi modal dasar untuk menyikapi pembelajaran yang sebenarnya yaitu kenyataan hidup.

Perlunya pengetahuan literasi keuangan dimaksudkan agar setiap individu memiliki kemampuan dalam menangani permasalahan keuangan.Literasi keuangan adalah pengetahuan tentang pengelolaan keuangannya sendiri agar lebih bijaksana dalam pengelolaan keuangan dan menjadikan hidup lebih sejahtera di masa yang akan datang.

Pentingnya pendidikan literasi keuangan adalah untuk melakukan edukasi di bidang keuangan kepada masyarakat Indonesia agar dapat mengelola keuangan secara cerdas (OJK, 2016).Literasi memiliki tujuan jangka panjang bagi seluruh golongan masyarakat.Jika edukasi pengelolaan keuangan ini ditanamkan atau diberikan dilingkungan keluarga sejak dini diharapkan setiap keluarga tersebut memiliki kemampuan mengelola keuangannnya dengan bijaksana, sehingga tercipta masyarakat yang sejaktera. Upaya meningkatkan literasi keuangan masyarakat tidak bisa dilakukan secara instan namun butuh proses yang panjang dan berkelanjutan (Gunartin, 2019).

Berdasarkan deskripsi literasi keuangan di atas maka sangat penting untuk menanamkan kemampuan mengelola keuangan sejak dini, dengan cara dari anak masih kecil sudah diajarkan menabung, membelanjakan uangnya karena kebutuhan bukan karena keinginan dan mengelola keuangannya sendiri agar cukup sesuai jatah yang telah ditetapkan. Untuk bisa menanamkan sikap bijaksana dalam pengeloaan keuangan tentu butuh proses yang dapat dimulai 


\section{Loyalitas Kreativitas \\ Aldi Masyarakat Kreatif}

P-ISSN 2722-2101, E-ISSN 2722-4201

Program Studi Ekonomi Manajemen Universitas Pamulang

Jurnal LOKABMAS Kreatif Vol. 01, No. 01, Hal. 56- 62

Email:jurnalkreatif.manajemen@gmail.com dari keluarga. Karena keluarga merupakan lingkungan yang pertama dikenal oleh anak, dan tumbuh kembang anak sangat didominasi pada lingkungan keluarganya. Begitu juga pemahaman tentang pengelolaan keuangan tidak kalah pentingnya untuk disosialisasikan sejak dini dengan cara dilatih menyisihakan uang sakunya untuk ditabung.Memberi kesempatan anak untuk berlatih mengelola uang sakunya jauh lebih baik dari pada anak dipaksa menabung. Karena jika dipaksa menabung anak hanya mengerti menyimpan uang dalam bentuk tabungan sebagai cadangan sewaktu waktu dibutuhkan., tapi mengelola keuangan tidak cukup hanya dengan menyimpan, tetapi justru bagaimana cara mengatasi permasalahan keuangannya sendiri.

Dengan diberikan pemahaman dan pendidikan tentang literasi keuangan di lingkungan keluarga diharapkan setiap anggota keluarga memahami benar kondisi keuangan keluarga tersebut.Untuk itu peran orang tua sangat penting dalam mensosialisasikan dan mendidik putra putrinya agar mampu mengelola keuangannya secara cerdas, tentu harus dimulai dari orang tua itu sendiri untuk lebih bijak dalam membelanjakan keuangannya.

Dengan adanya materi pada kegiatan ini tentang pendidikan literasi keuangan di lingkungan keluarga, diharapkan orang tua selaku pendidik di lingkungan keluargadapat berperan sebagaimana mestinya peran orang untuk memberikan edukasi kepada putra putrinya tanpa kecuali pendidikan mengelola keuangan secara efektif dan efisien sehingga kesejahteraan keluarga dapat diwujudkan, Pendidikan literasi keuangan juga dapat menjembatani terciptanya keterbukaan kondisi keuangan keluarga. Misalnya, jangan sampai anak tidak mau tahu akan kesulitan keuangan yang dialami orang tuanya. Oleh karena itu tim dosen pengabdian kepada masyarakat hadir untuk berbagi memberikan penyuluhan tentang pentingnya pendidikan literasi keuangan di lingkungan keluarga pada Majelis Ta'lim Al Hidayah Benda Baru Pamulang Tangerang Selatan.

\section{RUMUSAN MASALAH}

Dengan mempertimbangkan latar belakang yang telah diutarakan diatas kami berinisiatif melaksanakan pengabdian kepada masyarakat untuk keluarga anggota jamaah Majelis Ta'lim Al Hidayah melalui progam penyuluhan materi pentingnya pendidikan literasi keuangan di lingkungan keluarga. yang beralamatkan di Pamulang Regency Jl. H. Rean RT.008 RW.005 Benda Baru Pamulang Tangerang Selatan. Membekali keluarga terutama ibu-ibu, yang menjadi bendahara keluarga dan kepala rumah tangga, ibu-ibu memiliki peran yang sangat mulia sebagai pendidik sekaligus motivator bagi anggota keluarganya untuk menciptakan keluarga sejahtera..

\section{TUJUAN PELAKSANAAN}

1. Membantu mensosialisasikan kepada keluarga tentang pentingnya pendidikan literasi keuangan melalui ibu-ibu selaku bendahara kelauarga.

2. Memberikan motivasi agar setiap keluarga dapat menciptakan kesejahteraan ekonomi melalui keamanan finansial.

\section{TINJAUAN PUSTAKA}

\section{Pengertian Pendidikan}

Pendidikan mengandung banyak aspek dan sifatnya sangat kompleks. Karena sifatnya yang sangat kompleks itu, maka tidak ada batasan yang cukup memadai untuk menjelaskan arti pendidikan secara lengkap. Batasan tentang pendidikan yang dibuat oleh para ahli beraneka ragam dan memiliki kandungan yang berbeda-beda. Perbedaan tersebut mungkin karena orientasinya, konsep dasar yang digunakan, aspek yang menjadi tekanan, atau karena falsafah yang melandasinya.

Pendidikan menurut sudut pandang Elfachmi (2016), yaitu:

a. Pendidikan sebagai suatu sistem bahwa pendidikan dipandang sebagai keseluruhan gagasan terpadu yang mengatur usaha-usaha sadar untuk membina seseorang untuk mencapai harkat kemanusiaannya secara utuh.

b. Pendidikan sebagai proses bahwa pendidikan dipandang sebagai pelaksana 


\section{Loyalitas Kreativitas \\ Aldi Masyarakat Kreatif}

P-ISSN 2722-2101, E-ISSN 2722-4201

Program Studi Ekonomi Manajemen Universitas Pamulang

Jurnal LOKABMAS Kreatif Vol. 01, No. 01, Hal. 56- 62

Email:jurnalkreatif.manajemen@gmail.com usaha-usaha untuk mencapai tujuan tertentu dalam rangka mencapai harkat kemanusiannya yang utuh.

c. Pendidikan sebagai hasil bahwa pendidikan dipandang sebagai sesuatu yang telah dicapai atau dimiliki seseorang setelah proses pendidikan berlangsung.

Adapun batasan pendidikan menurut Mulyasa (2011), yaitu:

a. Bahwa pendidikan berperan membantu manusia untuk memahami rahasia dan cara hidup dibalik kehidupan. Dengan pemahaman tersebut, manusia dididik untuk dapat memahami arti, hakikat, dan tujuan hidup dengan benar.

b. Pendidikan membantu manusia melakukan proses penyesuaian diri dengan tuntutan perubahan dan dengan sesuatu yang baru. Menurut pandangan filsafat proses, segala sesuatu yang menempati ruang dan waktu pasti akan berproses. Setiap proses akan melahirkan perubahan, dan setiap perubahan akan melahirkan sesuatu yang baru. Disinlah pendidikan dan guru yaitu membantu peserta didik untuk dapat menyesuaikan diri dengan sesuatu yang baru.

c. Pendidikan membantu melepaskan manusia dari kebodohan, kemiskinan, dan keterbelakangan. Pendidikan membantu manusia melepaskan diri dari beban yang berat tersebut, sehingga diharapkan tumbuh kesadaran, tanggung jawab, semangat, ' motivasi manusia untuk melepaskan diri c kebodohan, kemiskinan, dan keterbelakangan.

Dari berbagai pengertian pendidikan tersebut, dapat disimpulkan bahwa pendidikan adalah pertolongan yang diberikan oleh orangorang dewasa dalam perkembangan anak untuk mencapai tujuan agar anak cukup cepat dalam melaksanakan tugas hidupnya sendiri tanpa bantuan orang lain.

\section{Literasi Keuangan}

Pada dasarnya, literasi keuangan adalah seperangkat keterampilan dan pengetahuan yang memungkinkan seorang individu untuk membuat keputusan dan efektif dengan semua sumber daya keuangan mereka (Luzuardi, dalam Manurung 2009).dalam penelitian
Widyawati (2012)mengartikan bahwa literasi keuangan sebagai kemampuan untuk memahami kondisi keuangan serta konsepkonsep keuangan dan untuk merubah pengetahuan itu secara tepat ke dalam prilaku. Sedang menurut penelitian Krisna (2008) juga mendefinisikan bahwa literasi keuangan sebagai kemampuan untuk menggunakan pengetahuan serta keahlian untukmengelola sumber daya keuangan agar tercapai kesejahteraan. Lebih sederhananya literasi keuangan dapat diartukan sebagai pengetahuan keuangan dengan tujuan mencapai kesejahteraan di masa yang akan datang.

Literasi keuangan juga dapat diartikan sebagai suatu kemampuan dan pemahaman tentang keuangan.Jadi literasi keuangan adalah kemampuan mengelola dana yang dimiliki agar berkembang dan bisa hidup lebih sejahtera dimasa yang akan datang. Misi penting dari program literasi keuangan adalah untuk melakukan edukasi dibidang keuangan kepada masyarakat Indonesia agar dapat mengelola keuangan secara cerdas, supaya rendahnya pengetahuan tentang industri keuangan dapat diatasi dan masyarakat tidak mudah tertipu pada produk-produk investasi yang menawarkan keuntungan tinggi dalam jangka pendek tanpa mempertimbangkan resikonya. Untuk memastikan pemahaman masyarakat tentang produk dan layanan yang ditawarkan oleh embaga jasa keuangan, program strategi tasional literasi keuangan mencanangkan tiga pilar utama.Pertama, mengedepankan program edukasi dan kampanye nasional literasi keuangan.Kedua, berbentuk penguatan infrastruktur literasi keuangan.Ketiga, berbicara tentang pengembangan produk dan layanan jasa keuangan yang terjangkau.Penerapan ketiga pilar tersebut diharapkan dapat mewujudkan masyarakat Indonesia yang memiliki tingkat literasi keuangan yang tinggi sehingga masyarakat dapat memilih dan memanfaatkan produk jasa keuangan guna meningkatkan kesejahteraan.

Berdasarkan pendapat-pendapat tentang literasi keuangan di atas dapat disimpulkan bahwa literasi keuangan merupakan cara membantu dalam memberikan pemahaman tentang mengelola keuangan dan peluang untuk 


\section{Loyalitas Kreativitas \\ Aldi Masyarakat Kreatif}

P-ISSN 2722-2101, E-ISSN 2722-4201

Program Studi Ekonomi Manajemen Universitas Pamulang

Jurnal LOKABMAS Kreatif Vol. 01, No. 01, Hal. 56- 62

Email:jurnalkreatif.manajemen@gmail.com mencapai kehidupan yang lebih sejahtera dimasa yang akan datang. Dengan kata lain literasi keuangan dapat digunakan sebagai salah satu alat bantu yang perlu ditingkatkan seseorang atau individu apabila mau mimiliki passive income yang melebihi aktive income.

\section{Keluarga}

Peranan wanita dalam aktivitas rumah tangga berarti wanita sebagai ibu rumah tangga.Dalam hal ini wanita memberikan peran yang sangat penting bagi pembentukan keluarga sejahtera sebagai unit terkecil dalam kehidupan bermasyarakat, berbangsa, dan bernegara.Kehidupan yang sehat sejahtera harus dapat dimanifestasikan dalam kehidupan sehari-hari. Menurut Kuswardinah (2007) untuk menciptakan suatu keluarga yang baik perlu didukung hal sebagai berikut :

a. Kesehatan jasmani harus diperhatikan, mulai dari kesehatan suami, istri, dan kesehatan anak sejak dalam kandungan, usia balita, hingga dewasa, gizi keluarga, hidup bersih serta teratur.

b. Kesehatan rohani harus diperhatikan, mulai dari sikap perilaku orang tua sejak anak masih dalam kandungan, mengajarkan pendidikan moral, sosial, dan agama dalam keluarga, serta menjadi tauladan bagi anakanaknya.

Keluarga berkualitas adalah keluarga yang dibentuk berdasarkan perkawinan yang sah dan bercirikan sejahtera, sehat, maju, mandiri, memiliki jumlah anak yang ideal, berwawasan kedepan, bertanggung jawab, harmonis dan bertakwa kepada Tuhan Yang Maha Esa

Ekonomi keluarga yang dapat menunjang kehidupan rumah tangga, yaitu adanya keseimbangan antara pengahasilan dan pengeluaran, menentukan skala prioritas, menambah pendapatan keluarga dengan pengelolaan keuangan yang efektif dan efisien.Wanita dalam keluarga sebagai kepala rumah tangga harus memiliki kemampuan literasi keuangan.Selaku kepala rumah tangga, seorang ibu menjadi ujung tombak kesejahteraan keluarganya. Dalam pengelolaan keuangan keluarga bukan berapa besarnya pendapatan dan kecilnya pengeluaran, tetapi juga harus mampu menyeimbangkan antara kebutuhan dan keinginan.Artinya, mana yang menjadi kebutuhan pokoh yang penjadi prioritas utama, dengan tujuan untuk membangun kesejahteraan keluarga.

Kesejahteraan keluarga adalah suatu kondisi dinamis keluarga dimana terpenuhinya semua kebutuhan fisik materiil, mental spiritual, dan sosial yang memungkinkan keluarga dapat hidup wajar/normal sesuai dengan lingkungannya serta memungkinkan anak-anak tumbuh kembang dengan baik dan memperoleh perlindungan yang diperlukan untuk membentuk sikap mental dan kepribadian yang matang sebagai sumber daya manusia yang berkualitas.

\section{METODE PELAKSANAAN}

Metodepelaksanaan pengabdian kepada masyarakat ini dilakukan dalam beberapa kegiatan yaitu tahap survei dengan melakukansilaturrohmi dan sosialisasi kepada ketua Majelis Ta'lim Al Hidayah untuk menyampaikan tentang rencana dan tujuan dari pelaksanaan pengabdian yang akan dilaksanakan oleh tim dosen Prodi Pendidikan Ekonomi Universitas Pamulang. Selain surve pendahuluan, tentu yang tidak kalah pentingnya adalah persetujuan dari pihak Majelis Ta'lim atas kesempatan yang diberikan untuk melaksanakan penyuluhan tentang pentingnya pendidikan literasi keuangan di lingkungan keluarga.

Tahap persiapan dilakukan dengan melengkapi dokumen dan segala sesuatu yang terkait pelaksanaan seperti: pembagian tugas dan tanggung jawab anggota tim pengabdi, menyiapkan daftar hadir, menyiapkan materi yang akan disampaikan, pemateri dan teknis pelaksanaan. Pelaksanaan pengabdian kepada masyarakat menyesuaiakan jadual rutin kajian Majelis Ta'lim Al Hidayah Benda Baru Pamulang yang diadakan dua minggu sekali, dengan maksud kegiatan dapat berjalan lancar dan tidak mengganggu waktu keluarga yang lain.

\section{HASIL DAN PEMBAHASAN}

Majelis Ta'lim Al Hidayah yang berlokasi di RT. 008 RW 005 Kelurahan Benda 


\section{Loyalitas Kreativitas \\ Aldi Masyarakat Kreatif}

P-ISSN 2722-2101, E-ISSN 2722-4201

Program Studi Ekonomi Manajemen Universitas Pamulang

Jurnal LOKABMAS Kreatif Vol. 01, No. 01, Hal. 56- 62

Email:jurnalkreatif.manajemen@gmail.com
Baru Kecamatan Pamulang Tangerang yang berdiri 10 Oktober 2017 dengan anggota ibuibu di komplek perumahan Pamulang Regency. Majelis Ta'lim Al Hidayah ini didirikan sebagai wadah kajian ke-Islam-an dan ajang silaturrohim bagi warga yang tinggal di perumahan Pamulang Regency.

Majelis Ta'lim Al Hidayah diprakakasai oleh bu Inna Alawiyah, S.Pd dan ibu-ibu yang lain dengan tujuan di komplek perumahan Pamulang Regency ada ajang silaturrohim dan wadah kajian ke Islam an untuk sharing ilmu dan pengalaman. Secara bertahap selama hampir 2 tahun ini jumlah anggota berkembang seiring berkembangnya jumlah penghuni perumahan Pamulang Regency. Sekarang jumlah jamaah Majelis Ta'lim Al Hidayah 40 orang karena tidak semua warga Pamulang Regency ikut dan beragama lain.

Kegiatan PengabdianMasyarakat Universitas Pamulang yang dilakukan oleh tim dosen program studi Pendidikan Ekonomi dapat berjalan dengan lancar dan mendapat respon yang luar biasa dari anggota Majelis Ta'lim AlHidayah Benda Baru Pamulang ,Tangerang Selatan. Pada kesempatan ini juga disampaikan agar kegiatan ini dapar berkelanjutan melalui program pengabdian kepada masyarakat.

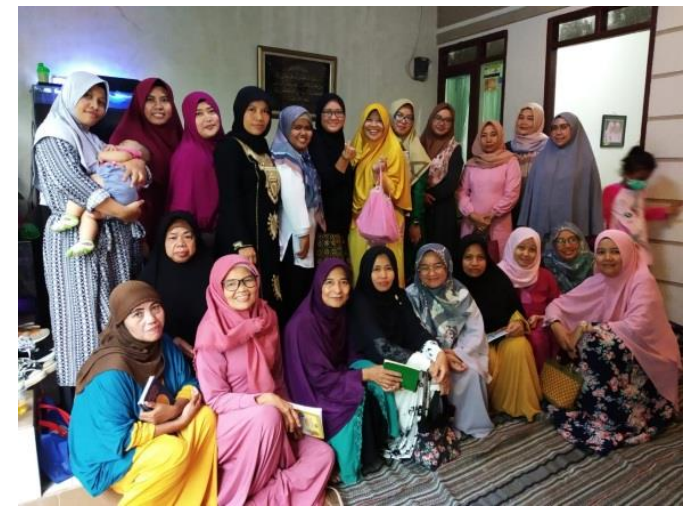

Dari kegiatan ini diharapkan dapat membuka wawasan dan terampil dalam mengelola keuangan keluarga, Berapapun besarnya pendapatan jika tidak dikelola dengan baik akan mendatangkan masalah di kemudian hari karena kebutuhan dari waktu ke waktu pasti akan meningkat seiring bertambahnya kebutuhan anak, terlebih jika anak sudah sekolah tentu semakin tingggi tingkat sekolah kebutuhannya semakin banyak. Sebaliknya sekecil apapun pendapatnya jika dikelola dengan efektif dan efisien hasilnya akan lebih baik karena keuangan dikelola secara cerdas dan kesejahteraan ekonomi keluarga akan dapat diwujudkan.

Pada era serba online seperti sekarang ini, berbagai penawaran yang menggiurkan lebih mudah dilakukan.Apalagi hidup diperumahan, budaya ingin memiliki barang sepert tetangganya masih marak terjadi.Jadi tidak heran apabila perilaku konsumtif masih membudaya di lingkungan perumahan. Jika kepala rumah tangga tidak memiliki kemampuan literasi keuangan untuk mengatur keuangan keluarganya yang ada akan mudah terpengaruh dan terbawa arus konsumtif. Pengelolaan keuangan tidak saja menjadi tanggung jawab ibu sebagai kepala rumah tangga, tetai seluruh anggota keluarga harus memahami bagaimana mengelola keuangan yang baik, sehingga saling mendukung dan saling memahami akan kebutuhan orang tua dan anak.

Pada umumnya yang berlaku di masyarakat, kepala keluarga mencari nafkah untuk memenuhi kebutuhan sehari-hari, kalau ada sisanya baru ditabung.Kalau polanya seperti itu sulit bagi keluarga untuk memiliki tabungan, yang ada malah mempunyai hutang, karena tidak ada cadangan untuk berjaga-jaga, terlebih untuk investasi guna passive incame, masih jauh dari realisasi.

Kegiatan pengabdian kepada masyarakat oleh tim dosen Prodi Pendidikan Universitas Pamulang ini hadir untuk memberikan penyuluhan tentang pentingnya pendidikan literasi di lingkungan keluarga ini karena tim dosen merupakan bagian dari masyarakat yang ikut bertanggung jawab atas kualitas sumber daya manusia di masyarakat, oleh karenanya dosen berkewajiban melakukan tridharma Peerguruan Tinggi dimaksudkan akan turut berkontribusi dalam pembangunan sumber daya ekonomi.

\section{KESIMPULAN DAN SARAN \\ Kesimpulan}

Secara umum keluarga yang menjadi anggota Majelis Ta'lim Al Hidayah dan tinggal 


\section{Loyalitas Kreativitas \\ Aldi Masyarakat Kreatif}

P-ISSN 2722-2101, E-ISSN 2722-4201

Program Studi Ekonomi Manajemen Universitas Pamulang Jurnal LOKABMAS Kreatif Vol. 01, No. 01, Hal. 56- 62

Email:jurnalkreatif.manajemen@gmail.com di komplek Pamulang Regency pola mengelola keuangan keluarganya masih konvensional. Artinya, besarnya pendapatan sama dengan besarnya pengeluaran dengan anggapan nanti akan berpendapatan lagi.Sehingga untuk masyarakat sekarang ini lebih mudah terbawa arus konsumtif.

\section{Saran}

Oleh karena itu pengetahuan tentang literasi keuangan itu penting untuk ditanamkan dan diedukasi dari lingkungan keluarga, agar menjadi insan yang menghargai sumber daya ekonomi.

\section{DAFTAR PUSTAKA}

Gunartin. 2019. Faktor-Faktor yang Mempengaruhi Financial Literacy (Studi Pada Mahasiswa Prodi Pendidikan Ekonomi Universitas pamulang), EDUKA, Vol. 4 No. 2 Tahun 2019

Krisna, (2008) "Analisis Tingkat Literasi Keuangan di Kalangan Mahasiswa dan Faktor-Faktor yang Mempengaruhinya: Survey pada Mahasiswa Universitas Pendidikan Indonesia". Proceedings of The 4th International Conference on Teacher Education; Join Conference UPI \& UPSI Bandung, Indonesia, 8-10 November 2010. Hal 552-560.

Luzuardi, 2011. Financial Literacy Around the Word An Oveview National Bureau of Economic Research, NBER working paper, 17 (170) 1-17

OJK, 2016.Strategi Nasional Literasi Keuangan Indonesia.

Pasaribu, V. L. D., Agrasadya, A., Shabrina, N., \& Krisnaldy, K. (2020). MENJADI ENTERPRENEUR MUDA YANG MEMILIKI JIWA LEADERSHIP UNTUK MENGHADAPI MASA DEPAN. Abdi Laksana, 1(1)

Pasaribu, V. L. D., Elburdah, R. P., Sudarso, E., \& Fauziah, G. (2020). PENGGUNAAN MANAJEMEN WAKTU TERHADAP PENINGKATAN PRESTASI BELAJAR DI SMP ARAISIYAH. Jurnal ABDIMAS, 1(1)
Pasaribu, V. L. D., Susanti, F., \& Hartuti, E. T. K. (2019). MEMOTIVASI SISWA DAN SISWI SMK LETRIS INDONESIA DI DALAM MENENTUKAN PILIHAN UNTUK MELANJUTKAN PENDIDIKAN ATAU BEKERJA SETELAH LULUS

SEKOLAH. Jurnal Pengabdian Dharma Laksana, 1(2), 161-172.

Wijayati Irin, Faktor Faktor yang Mempengaruhi Literasi Finansial Mahasiswa Fakultas Ekonomi dan Bisnis Universitas Brawijaya. Jurnal Akuntansi dan Pendidikan Volume 1 Nomor 1 Oktober 2012. 